\title{
Identifying the mastery of research statistical concept by using problem-based learning
}

\author{
Susbiyanto Susbiyantoํㅜ, Dwi Agus Kurniawan², Rahmat Perdana ${ }^{3}$, Cicyn Riantoni ${ }^{4}$ \\ ${ }^{1}$ Doctoral School of Education, Eötvös Loránd University, Hungary \\ ${ }^{2,3,4}$ Department of Physics Education, Universitas Jambi, Indonesia
}

\begin{tabular}{l}
\hline Article Info \\
\hline Article history: \\
Received Jul 17, 2019 \\
Revised Aug 19, 2019 \\
Accepted Aug 29, 2019 \\
\hline
\end{tabular}

Keywords:

Problem-based learning

Research statistical concept

Students

Mastery

\begin{abstract}
The consequence of the assessment for the research statistics course at the department of physics Education in Universitas Jambi demonstrates the students' capacities to hold the idea of the mastery of research statistical concept is very low. It winds up one of the shortcomings for them to finish their final assignment. Therefore, the researcher examined the student's mastery of the research statistical concept by utilizing Problem-Based Learning as one of the methods that were chosen from the learning advancement. The research method is quantitative with 295 numbers of samples. Questionnaires and MCQs were used as the instruments of the research. The result had been investigated utilizing a simple regression analysis. PBL influences the mastery of research statistical concept. In $6^{\text {th }}$ semester male students', the impact of PBL toward the mastery of the research statistical concept contributed $72 \%$ and $67 \%$ for female students. Meanwhile, for students at $8^{\text {th }}$ semesters, the impact of PBL on the mastery of research statistical concept contributed $68 \%$ for male and $70 \%$ for female.
\end{abstract}

Copyright $@ 2019$ Institute of Advanced Engineering and Science. All rights reserved.

\section{Corresponding Author:}

Dwi Agus Kurniawan,

Department of Teaching and Education,

Jambi University,

Lintas Jambi-Muaro Bulian Street KM. 15, 36361, Jambi, Indonesia

Email: dwiagus.k@unja.ac.id

\section{INTRODUCTION}

Based on the ministry of research of Indonesia, Technology and Higher Education Regulation Number 44 of 2015 concerning National Standards for Higher Education Article 46 section 1, 2, and 3 states that: (1) the procedure of standard research is a requirement for research activities comprising of planning, implementation, and reporting. (2) The research activities as alluded to in passage (1) are the activities that fulfill the scientific principle and methods systematically as per the independence of science and scholastic culture. (3) Research activities must consider about the quality, safety, healthy, comfort and safety standards of researchers, the community, and the environment [1]. This explanation shows that scientific work made by students as an essential for accomplishing an academic degree as a must achieve standards final errand that has been specified. Obviously, this condition some of the time turns into a substantial weight for them. The complexity of the final project which is confronted the students ended up as one of the triggers for them to procrastinate finishing their thesis [2]. The premise of this issue among others is the complexity of the bureaucracy to support students' last assignments and the absence of students' understanding to get the methodology and statistics that will be utilized [3]. Students will be worried all through doing their final assignments. Yet, control of supervisor and social support can lessen tension and stress experienced by students [2]. To maintain their research methodology and scientific concept, the Teacher has to have a commitment to give a decent technique that can be applied at the course. 
Seeing the significant role of teachers in training students' thinking skills will require a sufficient teaching strategy particularly for statistic subject. The statistic itself has a definition of the study of Taburing out how to design, gather, analyze, interpret, and present. Statistic are approaches to find out about how students are faced with advancement and interaction with statistical models and they could make integration into data samples, probabilistic models, contexts, and furthermore conclusions in a technology-enhanced learning environment [4]. The determination of learning techniques and how to apply, it is the key to enrich the accomplishment in statistical learning. This is identified with methods, procedures, and learning methodologies that will be actualized by the teacher to welcome student and receive learning material with fun. Each and every piece of the procedure has a solid connection and completes one another. Therefore, teachers must be cautious in dealing with these learning techniques.

An ideal learning will encourage the improvement of students' capacities and comprehension of the statistical concept. For instance, after completing the course, unquestionably, they have great skills in analyzing data, for example, analyzing descriptive statistical data and inferential statistics. They realize that descriptive statistics will provide an explanation about report trends and varieties in data centers with the goal that they can give data that can facilitate understanding of the result of the information obtained [5]. The result can be in the form of mean, middle, mode, standard deviation, minimum value, maximum value, quartile, and exhibited as pie graphs or data tables. In another side, students likewise know the function of inferential statistics that can be utilized to respond to inquiries in a research, where researchers examined information from research samples to draw conclusions about obscure populations and after that direct an investigation for any distinctions in groups or connections between variations, then at that point discover something greater or smaller than expected from the total of subject [5].

In terms of function, the statistical concept plays a significant role in day by day life. The role of statistics is to satisfy needs by tackling logical issues that are relevant to real-life [6]. However, in fact, the students of Physics Education Departement in Universitas Jambi still categorized as statistics, obviously, a statistic is a difficult thing to comprehend by them. Despite the fact that different instances of the application of statistics have been given by teachers and that idea has been given all more appropriately, they still find numerous hindrances to understand it. They are as well hard to discover an association with the statistic concept as the instrument that could be utilized to tackle the day by day issue and how to apply it. Abstain from engaging with numerous formulas and numbers that must be tallied is a motivation behind why students don't like statistics. This additionally makes students' interest to learn the statistical subject is low. It very well may be seen from their score after completed the final exam of the year and furthermore, the number of students to study this subject over again in each and every semester to improve their score because of their disappointment in the past semester is quite a lot.

Creative and innovative learning is needed as Efforts to direct students to be more active and creative in solving problems both in research and their activities later on. The success level of the teacher to complete their obligation is seen from the accomplishment of their students so it very well may be said that incredible teachers are they who can provide great motivation to students [7]. Innovation in education give many development for ideas, goods, methods, which are felt or observed as new things and as a consequences of an individual or gathering of individuals (society), either as an inversions (new discoveries) or inventions (new discoveries), which are utilized to accomplish teaching goals or to solve [8].

The effort to monitor and control the learning independently through various approaches, for example, cognitive adaptive, motivational or essential positive behavioral management strategies for learning and accomplishing learning objectives have been broadly applied [9]. Students nowadays are required to access knowledge and configure it independently [10]. Teachers need to utilize innovative and interactive teaching techniques to get improvements in the teaching process [11]. In order to improve the quality of education to produce graduates who are creative and ready to confront life in the future, innovation is required, one of which is by utilizing Problem Based Learning (PBL) as a learning strategy. The peculiar characteristic of PBL as a learning strategy is the emphasis on the issues as a medium to engage in learning and "students are likewise challenged to initiate their prior knowledge, to recognize their own learning objectives, and to contextualize their acquired knowledge" [12]. This condition illustrates that a learner plays a functioning role in learning, reducing the educator's role as a facilitator (tutor) [13].

Problem-based learning as a teaching and learning strategy has been designed to include students in tackling real-life problems [14]. It is a learning model that can improve students' critical thinking skills with procedural problem-solving activities. The results recommend further research by giving more systematic activities, so students can recollect issues in solving their critical thinking [15]. Problem-based learning is a teaching method and educational philosophy in which problem-solving is a mechanism that enables students to learn. Students work independently and in small groups to get information through problem-solving [16]. Problem-solving skills refer to the capacity of students to investigate solutions of issues given or discover approaches to understand the objectives given [17]. Creative thinking is expected to create thoughts to tackle 
issues and discover new methodologies. Meanwhile, teamwork is frequently a key segment in solving problems [18]. Students are tested to apply their insight in breaking down issues and improve their own learning limit among exchanges led by using the different learning assets they have, and furthermore they have the chance to apply the elaboration of each expanding knowledge toward the problem in the subsequent tutorial discussion [12].

Problem-based learning model has a good impact on learning. Based on the comprehension of the PBL itself specifically, Problem-based learning also has a close association with how the students learn. Subsequently, the use of PBL in statistics expected courses can provide the chance for students to gain a more profound comprehension of statistical concepts which is associated with genuine context through appropriate schemes in introducing solutions for problems that have been displayed in every lesson. And furthermore, students will improve their self-confidence alongside the increase of their comprehension of statistical concepts in each practice of solving problems as they follow by the lessons. In this unique circumstance, the study is intended to identify the impact of PBL utilization toward the mastery of research statistics concept at the Department of Physics Education in Universitas Jambi. The aim is to diminish the number of students that will delay completing the final assignment in the future through expanding comprehension of their statistical concepts.

\section{RESEARCH METHOD}

This study used descriptive research methods. It implies the setting of the fundamental design is described using words, numbers and current profiles, types of classification and also describes steps to respond to questions, such as who, when, where and how [19]. The descriptive approach was chosen because in this research, it will be seen how far students master the statistics concept for their research; the following, to discover students' response in the statistics course; then, to see the impact of problem-based learning on understanding students' statistical concepts at the Department of Physics Education in Universitas Jambi.

145 Students, who had studied statistics subject at $8^{\text {th }}$ semester and also 150 students who have studied statistics subject at $6^{\text {th }}$ semester, were recruited for this study. The utilized sampling technique was total sampling. Total sampling is the overall sampling technique of the population [20]. Total sampling was chosen as sample determination since researchers need to know the overall result from the existing population.

Data collection in this study draws upon a survey instrument. The occupied questionnaire sheet in the survey design was thoroughly studied and returned back to the researchers [5]. In addition to the questionnaire, the utilized data collection in this study used multiple-choice test instruments. In an attempt to get some complexity, chance can move towards different multiple-choice questions, where the range of choices was well provided [21]. Researchers need to know the level of capacity from students' statistical concept for the research of their thesis, therefore researchers were using the multiple-choice test as the instruments to gather the information.

The gathered data in this study were also obtained through interviews. The researchers' purpose of utilizing interviews as a data collection instrument is to examine more profoundly on the constraints felt by students when studying statistics independently for the final assignment. Researchers carried out qualitative interviews by giving a series of inquiries in front of one or more of the general participants and gather evident by taking notes and using sound recorder [5].

The flow of this research was commenced by providing a type of closed questionnaire where the alternative of the appropriate responses has been determined. The procedure for gathering the research data demonstrates the following Questionnaire Response; the Analysis of Questionnaire Responses, Independency Questionnaires, Interview, and Interview Analysis. The questionnaire is the techniques for collecting data where the participant or respondent fill and complete each and every single inquiry on the questionnaire sheet and return them back completely to the researchers [22]. The utilized questionnaire in this study is a response questionnaire of students to problem-based learning model, and the concept of comprehension with MCQs. Table 1 presents classification for the range of score for response questionnaire of problem-based learning. It can be seen that there are four categories, namely Very great, Well, Poor, and Bad.

Table 1. Categorization for the response questionnaire

\begin{tabular}{cc}
\hline Category & Score Range \\
\hline Very good & $58.6-72$ \\
Well & $45.1-58.5$ \\
Poor & $31.6-45$ \\
Bad & $18.0-31.5$ \\
\hline
\end{tabular}

Identifying the mastery of research statistical concept by using problem-based ... (Susbiyanto Susbiyanto) 
Data from the questionnaires have been analyzed using SPSS Software. The result has been processed into descriptive statistics. Descriptive information is in the form of data, median, mode, and frequency. Next, the researchers gave multiple-choice inquiries to students at $6^{\text {th }}$ and $8^{\text {th }}$ semester with four answer choices. The next following Table 2 is showing of score range categories for multiple-choice tests, where there are four classifications, namely Very good, Well, Poor, and Bad.

Table 2. Categorization to measure understanding of concepts by using multiple choice question

\begin{tabular}{cc}
\hline Category & Score Range \\
\hline Very good & $75.1-100$ \\
Well & $50.1-75$ \\
Poor & $25.1-50$ \\
Bad & $0-25$ \\
\hline
\end{tabular}

The data of multiple-choice test questions which have been analyzed were utilized as descriptive statistics. Next, researchers continue on collecting the data using a structured interview instrument. Interviews were conducted for all samples. The motivation behind the interview is to strengthen the result of the questionnaire and MCQs, and both score ranges are obtained from the comparison between the results of reduction from the most astounding and lowest score with the number of interval classes [23].

\section{RESULTS AND DISCUSSION}

In this section, the results of data analysis to measure students' ability to master the research statistical concepts by using multiple-choice test questions instrument was presented in Table 3. The frequency (f) and percentage $(\%)$ of every category level is the result of a descriptive analysis; to display more specific data, gender segregation is carried out in each semester. According the Table 3, it can be seen that 150 sampel from students at $6^{\text {th }}$ semester participated in the study, majority was female. Number of sampel at $8^{\text {th }}$ semester that participated in the study there were 145 students, majority was also female.

Table 3. Results of multiple-choice test questions instrument

\begin{tabular}{|c|c|c|c|c|c|c|c|}
\hline & \multicolumn{3}{|c|}{ Male } & & \multicolumn{3}{|c|}{ Female } \\
\hline & Category & Frequency & $\%$ & & Category & Frequency & $\%$ \\
\hline & Very good & 12 & 31.6 & & Very good & 23 & 20.5 \\
\hline Student 6 & Well & 19 & 50.0 & Student 6 & Well & 55 & 49.1 \\
\hline \multirow[t]{2}{*}{ Semester } & Poor & 5 & 13.2 & Semester & Poor & 21 & 18.8 \\
\hline & $\mathrm{Bad}$ & 2 & 5.2 & & $\mathrm{Bad}$ & 13 & 11.6 \\
\hline \multicolumn{2}{|c|}{ Total } & 38 & 100 & \multicolumn{2}{|c|}{ Total } & 112 & 100 \\
\hline & Very good & 3 & 8.6 & & Very good & 10 & 9.1 \\
\hline & Well & 10 & 28.6 & Student 8 & Well & 28 & 25.5 \\
\hline \multirow{2}{*}{ Semester } & Poor & 16 & 45.7 & Semester & Poor & 43 & 39.1 \\
\hline & Bad & 6 & 17.1 & & Bad & 29 & 26.3 \\
\hline \multicolumn{2}{|c|}{ Total } & 35 & 100 & \multicolumn{2}{|c|}{ Total } & 110 & 100 \\
\hline
\end{tabular}

Table 4 presents about student response questionnaire toward use PBL in statistical subjects. This table introduces the results of an analysis of the number of students who have given their responses as per the categories determined in the questionnaire sheet. The number of students who offered responses to every category was introduced in Frequency (f) and percentage (\%). The total sample from each semester and each gender that participated in this study is equivalent to Table 3.

Table 4. Student response questionnaire toward use PBL in statistical subjects

\begin{tabular}{|c|c|c|c|c|c|c|c|}
\hline \multicolumn{5}{|c|}{ Male } & \multicolumn{3}{|c|}{ Female } \\
\hline & Category & Frequency & $\%$ & & Category & Frequency & $\%$ \\
\hline & Very good & 10 & 26.3 & & Very good & 30 & 26.8 \\
\hline Student 6 & Well & 25 & 65.8 & Student 6 & Well & 74 & 66.1 \\
\hline \multirow[t]{2}{*}{ Semester } & Poor & 3 & 7.9 & Semester & Poor & 8 & 7.1 \\
\hline & $\mathrm{Bad}$ & 0 & 0 & & $\mathrm{Bad}$ & 0 & 0 \\
\hline \multicolumn{2}{|c|}{ Total } & 38 & 100 & \multicolumn{2}{|c|}{ Total } & 112 & 100 \\
\hline & Very good & 7 & 20.0 & & Very good & 30 & 27.3 \\
\hline Student 8 & Well & 23 & 65.7 & Student 8 & Well & 60 & 54.5 \\
\hline \multirow[t]{2}{*}{ Semester } & Poor & 5 & 14.3 & Semester & Poor & 20 & 18.2 \\
\hline & $\mathrm{Bad}$ & 0 & 0 & & $\mathrm{Bad}$ & 0 & 0 \\
\hline \multicolumn{2}{|c|}{ Total } & 35 & 100 & \multicolumn{2}{|c|}{ Total } & 110 & 100 \\
\hline
\end{tabular}


Regression hypothesis test was used to analyze of problem-based learning effect on mastery of research statistics. Table 5 shows the results of multiple regression analysis to overcome the effects of problem-based learning for the ability to master the study of statistical concepts.

Table 5. PBL effect on the students' ability to master statistical concepts empirically

\begin{tabular}{|c|c|c|c|c|c|c|c|c|c|c|c|c|c|}
\hline & \multirow{2}{*}{ Variables } & \multicolumn{6}{|c|}{ Male } & \multicolumn{6}{|c|}{ Female } \\
\hline & & Min & $\max$ & $\mathrm{X}$ & $\mathrm{P}$ & $\mathrm{R}$ & $\mathrm{R}^{2}$ & Min & Max & $\mathrm{X}$ & $\mathrm{P}$ & $\mathrm{R}$ & $\mathrm{R}^{2}$ \\
\hline $\begin{array}{l}\text { Student } \\
\text { Semester } 6\end{array}$ & Response PBL & 24 & 96 & 38.3 & 0.02 & 0.85 & 0.72 & 24 & 96 & 35.5 & 0.02 & 0.82 & 0.67 \\
\hline $\begin{array}{l}\text { Student } \\
\text { Semester } 8\end{array}$ & Response PBL & 24 & 96 & 34.9 & 0.03 & 0.83 & 0.68 & 24 & 96 & 36.5 & 0.02 & 0.84 & 0.70 \\
\hline
\end{tabular}

Based on the results of the analyzed data of students' capacity to master the statistical concepts for research which is shown in Table 3, that as many as $81.6 \%$ of $6^{\text {th }}$ semester male students, as well as $69.6 \%$ of $6^{\text {th }}$ semester female students, were both showing satisfying results. Of the $81.6 \%$ male students' results, $31.6 \%$ were within the Very Good category whereas $50 \%$ were within the Well category. Meanwhile, of the $69.6 \%$ female students' result, $20.5 \%$ were classified in the Very Good category and $49.1 \%$ were within the Well category. Compared to the $6^{\text {th }}$ semester students, a littler percentage was shown by the $8^{\text {th }}$ semester students who as well obtain satisfactory results. There were only $37.2 \%$ of male students and $34.6 \%$ of female students. The domination of Well category was acquired by $28.6 \%$ of male students and $25.5 \%$ of female students. The result shows $9.1 \%$ of the Very Good category result was acquired by the female students and only $8.6 \%$ of male students were in the Very Good category.

This indication shows that overall, the readiness of $6^{\text {th }}$ semester students to master the research statistical concepts are higher than $8^{\text {th }}$ semester students. $6^{\text {th }}$ semester students' acceptance to statistical concepts by using PBL is more comprehensive, as a result of more than $50 \%$ of them were able to choose the correct answer from the questions that have been given. On the other hand, more than $50 \%$ of $8^{\text {th }}$ semester students were unable to settle to the right answer. This tendency occurs because the various statistical concepts that have been learned are well-understood by $6^{\text {th }}$ semester students based on various problems according to the context they faced and also they were able to settle to the relevant concepts to resolve the issue which was conferred within the questions. In addition, the data employed in the queries were the data obtained from the results of students' practice when they were making observations in secondary school, making it easier for them to identify findings and relate them to existing statistical concepts. So concrete problems or which can be captured directly by the senses will be more easily understood by students. A supporting statement to this finding from previous research states that learning development based on student activity has a positive relationship with reflective observation learning style and it is shown vice versa in abstract conceptualization learning style [24]. Involvement in classroom activities significantly influences students' progress in overcoming various problems they face at university [25]. Other research also supports that student involvement in classroom activities promotes student performance specifically, where the metaanalysis test (using both a vote counting and a combined effect size method) has been conducted, showing that student involvement in class activities using PBL provides an effect positive and statistically significant especially in the application of their knowledge [26]. In addition, PBL also has a significant effect on the level of student knowledge concerning understanding principles that connect them to concepts.

Another distinct trend which was shown from the data obtained is that $6^{\text {th }}$ semester students are starting their initial steps to conduct research, they are being required to prepare research proposals for their final project. Therefore they still have not received high pressure from the final project they should complete. Whereas students in semester 8 are students who are doing researches, they focus more on problems that are linear with problems on the topic of their research studies and they attempt to avoid alternative things that will interfere their concentration. Based on the research results, almost $60 \%$ of students attempt to avoid various problems that can damage their concentration [3]. Students with a high level of internal pressure will actively be looking for more the information they need and use them to solve their problems and also try to complete their assignments immediately [2]. As the result, most of them are not too concerned about questions that are not associated to the domain of their research which they are working on, even though the various problems in the question have been simulated in their previous statistical learning activities. Many research results have revealed that the high intensity of students who practice using active and cooperative learning in their learning will shape student confidence and they consider themselves gaining knowledge and skills from the education they have gone through and see their college experiences as a useful thing [27]. This is in accordance with the results interviews of several $8^{\text {th }}$ semester students who have completed their research according to a predetermined schedule. Students are able to understand general concepts in statistics such as understanding the meaning of using descriptive statistics and inferential statistics and also the

Identifying the mastery of research statistical concept by using problem-based ... (Susbiyanto Susbiyanto) 
application of both techniques so that in the process of completing the final project, it will be easier for them to attach the problems they encounter. They hold their confidence to the concepts they understand because they properly have well understood the material obtained during college and this is the initial ground for them to set the right steps to solve the problems they would face in their research. (Students' interview, 2018).

The result of the analyzed of Students' response questionnaire toward the use of PBL in statistical subjects that have been exhibited in Table 4. The data demonstrates that most of $6^{\text {th }}$ and $8^{\text {th }}$ semester students gave a decent response. By and large, of the $6^{\text {th }}$ and $8^{\text {th }}$ semester students, the dominant response on the utilization of PBL was in the category of Well. About $66 \%$ of both $6^{\text {th }}$ semester male and female students gave their responses in this category, while in the $8^{\text {th }}$ semester students, the results for the well category were $65.7 \%$ of male students and $54.5 \%$ of female students. A smaller number of students were found in the higher rating which was the very good category. The very good category percentage was acquired approximately $26 \%$ by both male and female from $6^{\text {th }}$ semester students and $27.3 \%$ of female from semester $8^{\text {th }}$ reacted in a similar category, while male students had just $20 \%$. However, the Poor category tendency was leaning toward the $8^{\text {th }}$ semester students. The number was around $14 \%$ male and $18 \%$ female, while $6^{\text {th }}$ semester students just added up to $7.9 \%$ for male and $7.1 \%$ for female.

In general, the responses which were given by students to statistical learning utilizing PBL were good due to only $12 \%$ of the average result was stating a poor category and none of which acquired Bad classification. This indication demonstrates that the use of PBL learning pleases students due to the engagement between them and the statistical learning activities. Students get a different statistical learning atmosphere that was applied through PBL. They feel they have a sense of independence in expressing their ideas and have got the liberty to determine solutions to the problems they encounter. They believe they have an opportunity in conveying their thoughts and have the opportunity to decide the answers for the issues they face. Additionally, they are bound to have a role in a real group situation, so students reach a point of encountering wonderful experiences in learning statistics. Students conveyed this condition in the interviews that have been conducted. Most of the students who were interviewed felt that they were more open in exploring their ability to solve various problems that had been given in statistical learning. They are very happy to collaborate, giving complement to each other in their groups, find various solutions through collaboration and use them to solve the problems they encounter. They also consider that the differences in the solutions that will have been obtained from each group are natural and they give a great appreciation of these differences (Students' interview, 2018).

Some researchers have said that PBL has a positive contribution to learning including; access and utilisation of resources, Independent learning skills, critical thinking skills, scientific process skills (observing, classification, measurement, estimation, and deduction), the capacity to work in cooperative groups, communication abilities, research skills, problem solving skills [28]. The utilization of PBL in learning gives students the practice of problem-solving in which not only focus on understanding the material but they are also trained to analyze, evaluate, and draw conclusions to find solutions for the problems given [29]. Through the application of PBL, students are not simply attempting or searching for the correct single answer, yet understudies are prepared to assess several choices of solutions as alternatives. Obviously, the solutions are acquired through a series of activities; deciphering issues, gathering data, lastly perceiving different potential solutions [30].

The presence of genuine issues that fit the learning context or complex problems simulation in statistical learning utilizing PBL has encouraged students (in small groups) to cooperate to investigate a great deal of knowledge. Students are progressively dynamic and creative in their groups, supporting each other to discover different resources that can be utilized to handle the issues they face. They share new information and together recognizing the issues, discover thoughts and formulating steps to solve possible issues and draw conclusions. Such activities can encourage the improvement of students' creative thinking [31], and this can also be utilized as one of the media to rehearse higher-order thinking skills and furthermore to train students' gregarious life, since genuinely PBL is one type of constructivist learning that can possibly improve students' science process [32].

Generally, PBL as a learning approach has an exceptional characteristic that is utilizing genuine issues as the triggers in learning, at that point students attempt to solve these issues in small groups and the teacher takes on his role as a facilitator [30]. In spite of the fact that students are seemingly more dominant in learning activities, the teacher additionally has a significant role in giving a presentation, encouraging the learning process and guaranteeing that the learning procedure is going admirably. In learning activities which PBL is engaged, the teacher is a learning facilitator and not standing as a source of students' information [33]. Then followed by the most significant assignment for a teacher is to guarantee that the learning activities happen properly as per the plans which have initially been readied [34]. The obtained results from interviews that have been conducted demonstrate that, at several meetings, there was an indication of a weakness that 
emerges when the teacher facilitates statistical learning utilizing PBL. Based on the results of the investigation, the weakness is in the communication built by the teacher to students. This is assumed to be the main factor that causes some students to experience obstacles in participating in statistical learning activities.

The quality of communication among teacher and students in learning by utilizing PBL is a significant part since the teacher is considered as a partner as well as a member whose role actively takes place during the learning activities [36]. The teacher has the obligation to utilize great correspondence and providing understandable feedback received from students. Furthermore, specifically directing the learning activities to fit between the learning plan and the progressing learning process [36]. The teacher can alter their role and influence the ongoing process within the group, all relying upon the experience which is being faced by the students. Improving students' involvement in PBL requires a more elevated amount of freedom and self-sufficiency [37]. Subsequently, the teacher learning and comprehension of the subject being discussed is significant [12]. The teacher will have deterrents in facilitating discussions and furthermore in serving the issue with the investigation that will have been done by the students. This weakness will be a significant note for improving statistical learning later on, particularly for the Department of Physics Education in the University of Jambi.

Nevertheless, the result of regression hypothesis test that was used to analyze of problem-based learning effect on mastery of research statistics in general, it has shown a positive effect. Based on the data presented in Table 5, PBL gives an influence on the mastery of the statistical concept of research in semester $6^{\text {th }}$ students, with a significance value is $<0.05$. The contribution of the PBL effect to the mastery of research statistical concept for male students in $6^{\text {th }}$ semester is $72 \%$. Other factors that contribute to the PBL effect on mastery of concepts for them are $28 \%$. Meanwhile, the contribution of the PBL effect to mastery of research statistics concept for female students on semester $6^{\text {th }}$ is $67 \%$. Others factors that contribute to the effect of PBL on mastery of concepts for $6^{\text {th }}$ semester female students are $33 \%$. Another factor that influences PBL on mastering the concept of $6^{\text {th }}$ semester students is that students autonomously to find concepts that they need to know and adapt to the main problems given by the teacher. In accordance with that [16]; one of the key success on PBL is to facilitate the independence of student to work together in small groups, the process will enrich their knowledge gradually. Students' concepts retention will be stronger So that the concepts found by students will be intense to remember.

Table 5 also presents about PBL effects on mastery of statistical research concepts for the student on the $8^{\text {th }}$ semester. The results of the analysis presented in the table show that PBL also influences the mastery of the statistical concept of research in $8^{\text {th }}$ semester students, because the significance value is $<0.05$. Contribution of PBL's influence to the mastery of concepts in the $8^{\text {th }}$ semester male students was $68 \%$. Another factor that contributed to the effect of PBL on mastery of concepts in $8^{\text {th }}$ semester male students was $32 \%$. The contribution of PBL's influence on mastery of concepts in $8^{\text {th }}$ semester female students was $70 \%$. Another factor that contributed to the effect of PBL on mastery of concepts in female students in semester $8^{\text {th }}$ was $30 \%$. Another factor that has an influence on students in semester $8^{\text {th }}$ is the presence of PBL as a learning model for students in semester $8^{\text {th }}$ directly trains them to familiarize themselves with group discussions and to help students activate their prior knowledge. In cooperative group work, each team member is responsible not only for learning what is taught but also for assisting other group members to learn and create success within. It can be said that students learn effectively when they work cooperatively. This reinforces the explanation that was previously presented that the PBL approach enables students to obtain effective skills for problem-solving through various studies and experiences in the accumulation of knowledge through learning, teamwork, various subjects and disciplines [38]. So when students take their final assignments as subjects that must be completed in their final semester. Students are used to solving various problems that exist around the subject of their final project.

\section{CONCLUSION}

It very well assumes that the Problem Based Learning that has been applied in the subject of statistics at the Department of Physics Education in the University of Jambi contributes to the capacity of students to master statistical concepts. For the $6^{\text {th }}$ semester male students, $72 \%$ contribution of the PBL's effect on the mastery of the statistical concepts was obtained. Different with the percentage which was obtained by the $6^{\text {th }}$ semester female students that are $67 \%$. Meanwhile, for the $8^{\text {th }}$ semester male students, the percentage of the effect of PBL on the mastery of the statistical concepts was $68 \%$ and contributed $70 \%$ for the $8^{\text {th }}$ semester female students. These outcomes demonstrate that there is an impact of PBL on the mastery of the research statistics concept with a significance value of $<0.05$. Students are not only trained to get answers within the learning process but more emphasis on how they obtain the answers through a scientific approach they use. The level of students' knowledge can be identified through a variety of solutions they find to solve the problems. Each and every learning process they experience, gradually enhance their selfconfidence, process abilities, critical thinking skills, and high-order thinking skills. The teamwork which is

Identifying the mastery of research statistical concept by using problem-based ... (Susbiyanto Susbiyanto) 
applied in statistical learning utilizing PBL acculturates students to live respectively in groups, respecting and helping one another. This turns into the result for them to do the final project. Since the help of associates makes a noteworthy commitment in helping the completion of the students' final project.

Almost $88 \%$ of students give a decent reaction to the utilization of PBL in statistical learning. However, inadequate communication adversary affects learning activities. It tends to be prescribed to universities to encourage teacher competency improvement through pieces of training, particularly for subjects that include PBL in them. Moreover, consider the utilization of The Learning and Study Strategies Inventory (LASSI) to support the utilization of PBL actualized by the teacher in research statistics courses. In addition to assessing the impact of program interventions on overall students' results, this strategy can also be used to help students understand the material easily so that it can support the completion of their theses. This step can be reviewed further, especially to solve the classic problem of reducing the number of students who will postpone their graduation in the future.

\section{REFERENCES}

[1] Ministry of Research, Technology, and Higher Education, "The standard of higher education," In Number 44, Article 46, Paragraph (1), (2), and (3), Jakarta: Regulations of the Indonesian Ministry of Research, Technology and Higher Education, 2015.

[2] W.L. Sari and F. Fakhruddiana, "Internal locus of control, social support and academic procrastination among students in completing the thesis," International Journal of Evaluation and Research in Education (IJERE), vol. 8, no. 2, pp. 363-368, 2019.

[3] Z.M. Tatan, "Analysis of the final task procrastination," in The National Conference of Matematika dan Pendidikan Matematika, FMIPA UNY Yogyakarta, 2012.

[4] M. Pfannkuch, D. Zvi-Ben and Budgett, "Inovasi in statistical modeling to connect the data, chance and konteks," Springer, 2014. https://doi.org/10.1007/s11858-018-0989-2, 2-11.

[5] J.W. Creswell, "Educational research quantitative and qualitative," Lincoln: University of Nebraska, 2012.

[6] E. Reston, S. Krishna, "Statistics education research in Malaysia and the Philippines: A comparative analysis," International Association for Statistical Education, vol. 13(2), pp. 218-231, 2014.

[7] A. Sofanudin and F. Rokhman, "Quality-oriented management of educational innovation at Madrasah Ibtidaiyah," Journal of Education and Practice, vol. 7(27), pp. 176-180, 2016.

[8] I. Kunnari and L. Ilomäki, "Reframing teachers' work for educational innovation," Innovations in Education and Teaching International, vol. 53(2), pp. 167-178, 2016.

[9] P.R. Pintrich, The role of goal orientation in self-regulated learning, Handbook of Self-Regulation, pp. 451-502. https://doi.org/10.1016/B978-012109890-2/50043-3, 2000.

[10] M. Tezer, et all., "Content analysis of master's degree and doctorate theses where social skills training is approached," International Journal of Cognitive Research in Science, Engineering and Education (IJCRSEE), vol. 7(1), pp. 43-49, 2019.

[11] T. Rabgay, "The effect of using cooperative learning method on tenth grade students' learning achievement and attitude towards biology," International Journal of Instruction, vol. 11(2), pp. 265-280, 2018.

[12] T.S. Prihatiningsih and N. Qomariyah, "Evaluation of a problem based learning curriculum using content analysis," International Journal of Evaluation and Research in Education (IJERE), vol. 5, no.3, pp. 205-210, 2016.

[13] L. Ansarian and F.S Mohammadi, "Problem based learning in action: Review of empirical studies," Social Science \& Humanities, vol. 26, pp. 13-32, 2018.

[14] C. Vandenhouten, J. Groessl and E. Levintova, "How do you use problem-based learning to improve interdisciplinary thinking?," New Directions for Teaching and Learning, pp. 117-133, 2017.

[15] R. Rusmansyah, et al., "Innovative chemistry learning model: improving the critical thinking skill and self-efficacy of pre-service chemistry teachers," Journal of Technology and Science Education, vol. 9(1), pp. 59-76, 2019.

[16] C.M. Gillette, "Consideration of problem-based learning in athletic training education," Athletic Training Education Journal, vol. 12(3), pp. 195-201, 2017.

[17] N. Zhong, Y. Wang and V. Chiew, "Proses kognitif pemecahan masalah manusia," Penelitian Sistem Kognitif, vol. 11, pp. 81-92, 2010.

[18] S. Winarno, K.S Muthu and L.S. Ling, "Direct problem-based learning (DPBL): A framework for integrating direct instruction and problem-based learning approach," International Education Studies, pp. 1-8, 2018.

[19] L.W. Neuman, "Basics of social research: Qualitative \& quantitative approaches," England: Pearson Education Limited, 2014.

[20] F.N. Kerlinger, "Foundations of behavioural research," Yogyakarta: Gadjah Mada University Press, 2014.

[21] L. Cohen, L. Manion and K. Morrison, "Research methods in education," London: Rouledge Falmer, 2005.

[22] J.W. Creswell, "Research design qualitative, quantitative, and mixed method approach," Singapore: SAGE Publications Asia-Pacific, 2009.

[23] E.P. Widoyoko, "Research instrument preparation techniques," Yogyakarta: Pustaka Pelajar, 2012.

[24] A. Sirin and A. Güzel, "The relationship between learning styles and problem-solving skills among college students," Educational Sciences: Theory \& Practice, vol. 6(1), pp. 255-264, 2006. 
[25] M.Q. Duong, "Analytical evaluation of college learning experiences on students problem-solving efficacy among technical and scientific areas," International Journal of Evaluation and Research in Education (IJERE), vol. 1(2), pp. 67-72, 2012.

[26] F. Dochy, M. Segers, P. Van den Bossche and D. Gijbels, "Effects of problem-based learning: A meta-analysis," Teaching and Learning in Medicine, vol. 13, pp. 533-568, 2003.

[27] J. M. Braxton, J.F. Milem and A.S. Sullivan, "The influence of active learning on the college student departure process," The Journal of Higher Education, vol. 71(5), 569- 590, 2000.

[28] C. Tosun and Y. Taskesenligil, "The effect of problem-based learning on undergraduate students' learning about solutions and their physical properties and scientific processing skills," Chem Educ. Res. Pract, vol. 14(1), pp. 3650, 2013. DOI: 10.1039/c2rp20060k.

[29] M.D. Saputra, et al., "Developing critical-thinking skills through the collaboration of jigsaw model with problembased learning model," International Journal of Instruction, vol. 12(1), 2019.

[30] K.H. Roh, "Problem-based learning in mathematics," In ERIC Digest, ERIC Identifier: EDO-SE-03-07, 2003.

[31] E, Ersoy, "The effects of problem-based learning method in higher education on creative thinking," Procedia-Social and Behavioral Sciences, vol. 116, pp. 3494-3498, 2014.

[32] H.J. Duda, H. Susilo and P. Newcombe, "Enhancing different ethnicity science process skills: Problem-based learning through practicum and authentic assessment," International Journal of Instruction, vol. 12(1), 2019.

[33] R. Boelens, B. D. Wever, Y. Rosseel, A. G. Verstraete and A. Derese, "What are the most important tasks of tutors during the tutorials in hybrid problem-based learning curricula?," BMC Medical Education, vol. 15, pp. 84, 2015.

[34] H. S. Barrows, "Practice-based learning: Problem-based learning applied to medical education," Springfield, IL, USA, Souther Illinois University School of Medicine, 1994.

[35] G. Gorghiu, et al., "Problem-based learning - An efficient learning strategy in the science lessons context," Procedia - Social and Behavioral Sciences, vol. 191, pp. 1865-1870, 2015.

[36] B.D. Permatasari, Gunarhadi, Riyadi, "The influence of problem based learning towards social science learning outcomes viewed from learning interest," International Journal of Evaluation and Research in Education (IJERE), vol. 8(1), pp. 39-46, 2019.

[37] S. Turan, M. Elcin, O. Odabasi, K. Ward, and I. Sayek, "Evaluating the role of tutors in problem-based learning sessions," Procedia Social and Behavioral Sciences, vol. 1, pp. 5-8, 2009.

[38] D. Demirel, "Effects of problem-based learning on attitude: A metaanalysis study," Eurasia Journal of Mathematics, Science \& Technology Education, vol. 12(8), pp. 2115-2137, 2016. 